\title{
In vitro Evaluation of Anti-Chikungunya Virus Activities of Tualang Honey
}

\author{
Barkhadle, N.I. ${ }^{1}$, Mohamud, R. ${ }^{2}$, Mat Jusoh, T.N.A. ${ }^{1}$, Shueb, R.H. ${ }^{1,3^{*}}$ \\ ${ }^{1}$ Department of Medical Microbiology and Parasitology, School of Medical Sciences, Health Campus, Universiti Sains Malaysia, 16150 Kubang Kerian, \\ Kelantan, Malaysia \\ ${ }^{2}$ Department of Immunology, School of Medical Sciences, Health Campus, Universiti Sains Malaysia, 16150 Kubang Kerian, Kelantan, Malaysia \\ ${ }^{3}$ Institute for Research in Molecular Medicine (INFORMM), Universiti Sains Malaysia, 16150 Kubang Kerian, Kelantan, Malaysia \\ *Corresponding author: hanimshueb@gmail.com
}

\section{ARTICLE HISTORY}

Received: 7 August 2020

Revised: 10 November 2020

Accepted: 17 November 2020

Published: 25 March 2021

\begin{abstract}
Chikungunya is an infection caused by chikungunya virus (CHIKV). Although chikungunya has affected many countries in recent times, specific treatment or licensed vaccine are nonexistent. In this study the potential antiviral properties of Tualang honey against in vitro CHIKV infection was evaluated. Cytotoxic test was performed using the XTT Cell Viability assay to determine maximum non-toxic dose (MNTD) in Vero cells. Using plaque assay, the potential antiviral activities of Tualang honey at various non-toxic concentrations and treatment regimens were evaluated. Tualang honey demonstrated virucidal effect with maximum inhibition CHIKV observed was $99.71 \%(p<0.05)$. Tualang honey also had a prophylactic property by conferring protection to Vero cells during pre-treatment assay, resulting in up to $98.22 \%$ reduction of $\mathrm{CHIKV}$ replication under certain treatment regimen. Furthermore, Tualang honey exhibited anti-viral activities, with as much as $94.87 \%$ inhibition following post-treatment assay of Tualang honey in CHIKV-infected Vero cells. Additionally, Tualang honey also affected viral entry up to $82.21 \%$ after 48 hours of infection. These results suggest that Tualang honey has wide anti-CHIKV activities in Vero cells and exerts its effect through different mechanisms although these need to be further validated in other cells or model of CHIKV infection.
\end{abstract}

Keywords: Chikungunya, Tualang honey, antiviral, virucidal.

\section{INTRODUCTION}

Chikungunya is an infection caused by chikungunya virus (CHIKV) which is transmitted mainly by two species of Aedes mosquitoes; Aedes aegypti and Aedes albopictus (Morrone, 2007; La Beaud, 2008). CHIKV was first identified in Tanzania in 1952 and previous outbreaks have been confined to Africa and Asia (Perera-Lecoin et al., 2016; Sanyaolu et al., 2016). However, a global CHIKV epidemics that started in Kenya and spread to La Reunion Island in 2005-2006 followed by other countries was a major event that saw the spread of CHIKV to countries including India, Europe, the Caribbean, Latin America and South East Asia (Schuffenecker et al., 2006; Morrison, 2014). Chikungunya may induce similar clinical manifestations to dengue and Zika (Heang et al., 2012; Deeba et al., 2016) including joint swelling and pain, fever, rashes, headache and muscle pain (Naresh Kumar et al., 2007).

Despite its health threat, there is no exclusive antiviral agent or vaccine to treat or prevent CHIKV infection (Devasvaran \& Yong, 2016). Alternative therapy for chikungunya using drugs that are used to treat other infections such as chloroquine, arbidol, ribavirin have been investigated, although there are issues regarding their effectiveness. Chloroquine has prophylaxis properties (Bernard et al., 2010) but it is ineffective in the late stage of infection when tested in vivo and during clinical trial (De Lamballerie et al., 2008; Khan et al., 2010). Ribavirin exhibits antiviral activity against CHIKV in vitro particularly when combined with doxycycline (Rothan et al., 2015). However, ribavirin is only effective during the early stage of CHIKV life cycle (Mishra et al., 2016). The antiviral properties of medicinal plants and their derivatives against CHIKV infection, albeit at in vitro level, have also been investigated by many. These include studies on Vernonia amygdalina (Chan et al., 2016), curcumin from Curcuma longa (Von Rhein et al., 2016), Epigallocatechin-3-gallate (EGCG) derived from green tea (Steinmann et al., 2013), and silymarin extract from Silybum marianum's fruit (Lani et al., 2015). These compounds exert their effects against CHIKV through various mechanisms including direct inactivation of virus, blocking of CHIKV entry into cells and interruption of protein synthesis although the in vivo potential use of these compounds is unknown yet.

Tualang honey is a local Malaysian honey which is gathered from the honey combs of giant honey bee, Apis dorsata (Ahmed \& Othman, 2013). The bees build their hives on Tualang tree (Kompassia excels) which is commonly found in Malaysian tropical forests (Bashkaran et al., 2011). Similar to other honeys, Tualang honey also exhibits antibacterial 
effects against a wide range of bacteria including Salmonella typhi, Escherichia coli and Shigella sonnie (Ahmed \& Othman, 2013). Unfortunately, there is a dearth of evidence on the antiviral properties of Tualang honey which warrants further investigation. This current study was a preliminary study designed to examine the effect of Tualang honey on in vitro CHIKV replication.

\section{MATERIALS AND METHODS}

\section{Honey}

Tualang Honey was a kind gift from Prof. Siti Amrah Sulaiman. Five gram of fresh honey was diluted in $10 \mathrm{~mL}$ Dulbecco's Modified Eagle Media (DMEM) and filtered using $0.22 \mu \mathrm{m}$ syringe filter. Further dilution was prepared as required during subsequent experiments.

\section{Cell Lines}

Vero cells were maintained in DMEM, containing $5 \%$ of foetal bovine serum (FBS), 25 mM 4-(2-hydroxyethyl)-1piperazineethanesulfonic acid (HEPES) and penicillin/ streptomycin and subsequently grown at $37^{\circ} \mathrm{C}$ with $5 \% \mathrm{CO}_{2}$.

\section{CHIKV}

CHIKV used in this study was originally isolated from a patient and was a kind gift from Prof. Shamala Devi (Universiti Malaya). CHIKV was propagated in Vero cells and viral titres were determined by plaque assay.

\section{Cytotoxicity assay}

Cytotoxicity test was performed to determine the maximum non-toxic dose (MNTD) of Tualang honey. Vero cells at $2 \times 10^{4}$ cells per well were seeded overnight in 96 -well plates. After incubation, following washing with PBS, the cells were treated with different Tualang honey concentrations in triplicates. Healthy cells without honey were used as a negative control, whereas cells treated with 5\% DMSO in DMEM were used as a treated positive control as DMSO induces cell death in cells, followed by incubation for 48 hours at $37^{\circ} \mathrm{C}$ with $5 \% \mathrm{CO}_{2}$. Then, the XTT Cell Viability Assay was added to the cells for 3 hours at $37^{\circ} \mathrm{C}$ with $5 \% \mathrm{CO}_{2}$. The absorbance was read using ELISA plate reader at $475 \mathrm{~nm}$. Cell viability was calculated as described in Mohamat et al. (2018).

\section{Virucidal activity of Tualang honey}

Virucidal activity is when particular compound has the ability to inactivate or kill free virus directly outside of infected host. Different amounts of CHIKV; $2 \times 10^{5}, 2 \times 10^{4}$ and $2 \times 10^{3}$ $\mathrm{pfu} / \mathrm{mL}$, were directly treated with different concentrations of honey; $5 \mathrm{mg} / \mathrm{mL}, 10 \mathrm{mg} / \mathrm{mL}, 15 \mathrm{mg} / \mathrm{mL}$ and $20 \mathrm{mg} / \mathrm{mL}$ in triplicates for 2 hours at $37^{\circ} \mathrm{C}$ with $5 \% \mathrm{CO}_{2}$. Following incubation, the inhibitory effect was determined by plaque assay. The experiments were done in duplicates or triplicates and repeated three times.

\section{Pre-treatment assay}

Vero cells were seeded ( $1 \times 10^{5}$ cells per well) in a 24 -well plate and incubated overnight. The cells were then washed with PBS before pre-treated with different concentrations of honey; $5 \mathrm{mg} / \mathrm{mL}, 10 \mathrm{mg} / \mathrm{mL}, 15 \mathrm{mg} / \mathrm{mL}$ and $20 \mathrm{mg} / \mathrm{mL}$ in triplicates for 2, 4, 6, 12 or 24 hours. Following this, the cells were washed with PBS and infection of CHIKV was done at a multiplicity of infection (MOI) of 0.05 prior to incubation at $37^{\circ} \mathrm{C}$ for 1.5 hours. The cells were washed with PBS and were then supplemented with DMEM medium containing $1 \%$ FBS and were further incubated at $37^{\circ} \mathrm{C}$ with $5 \% \mathrm{CO}_{2}$. The supernatants from CHIK-infected Vero cells were subsequently harvested 48 hours post infection (hpi) to determine viral titre. The experiments were done in duplicates or triplicates and repeated three times.

\section{Post-treatment assay}

Vero cells were seeded in a 24 -well plate $\left(1 \times 10^{5}\right.$ cells per well) incubated overnight at $37^{\circ} \mathrm{C}$ with $5 \% \mathrm{CO}_{2}$. The cells were infected with CHIKV at $\mathrm{MOI}$ of 0.05 for 1.5 hour. The infected cells were washed twice with PBS to remove the un-absorbed virus and incubated with the different concentrations of honey; $5 \mathrm{mg} / \mathrm{mL}, 10 \mathrm{mg} / \mathrm{mL}, 15 \mathrm{mg} / \mathrm{mL}$ and $20 \mathrm{mg} / \mathrm{mL}$ in triplicates for $0,2,4,6$ or 8 hours at $37^{\circ} \mathrm{C}$ with $5 \% \mathrm{CO}_{2}$. The supernatants were harvested after 48 hpi CHIKV infection. The experiments were performed in duplicates or triplicates and repeated three times.

\section{Anti-adsorption assay}

$1 \times 10^{5}$ cells per well were seeded in 24-well plates overnight. The cells were infected with CHIKV at $0.05 \mathrm{MOI}$, and added with honey before being incubated at $4^{\circ} \mathrm{C}$ for 1 hour. Following this, the treated Vero cells were washed three times with PBS to remove the non-adsorbed virus, and subsequently supplemented with DMEM containing $2 \%$ FBS and incubated at $37^{\circ} \mathrm{C}$ with $5 \% \mathrm{CO}_{2}$. Following this, supernatants were collected $48 \mathrm{hpi}$ to determine viral titre. The experiments were performed in duplicates or triplicates and repeated three times.

\section{Anti-entry assay}

Confluent Vero cells in 24-well plates were infected with CHIKV (MOI 0.05) for 1 hour at $4^{\circ} \mathrm{C}$. The infected cells were washed twice with PBS to remove the non-adsorbed virus, and then treated with different concentrations of Tualang honey, $5 \mathrm{mg} / \mathrm{mL}, 10 \mathrm{mg} / \mathrm{mL}, 15 \mathrm{mg} / \mathrm{mL}$ and $20 \mathrm{mg} / \mathrm{mL}$, in triplicates for 2 hours at $37^{\circ} \mathrm{C}$ with $5 \% \mathrm{CO}_{2}$. The cells were washed again with PBS before were added with citrate buffer $(\mathrm{pH} 3)$ to inactivate the non-internalized viruses. The cells were washed again three times with PBS before supplemented with DMEM containing $2 \%$ FBS and incubated for 48 hours at $37^{\circ} \mathrm{C}$ with $5 \% \mathrm{CO}_{2}$. Viral titres were determined from the CHIK-infected Vero cells' supernatants. The experiments were performed in duplicates or triplicates and repeated three times.

\section{Plaque assay}

Plaque assay was performed to determine CHIKV titres in supernatants collected from virus-infected and honeytreated samples. The assay was performed by seeding Vero cells in a 24-well plate. Then, the supernatants were diluted 10 -fold in DMEM media supplemented with $1 \%$ FCS and 100 $\mu \mathrm{l}$ was added onto Vero cells prior to incubation for 3 hours. Subsequently, Vero cells were overlaid with $500 \mu$ l of $4 \%$ carboxymethylcellulose in DMEM. The cells were incubated for 3 days at $37^{\circ} \mathrm{C}$ with $5 \% \mathrm{CO}_{2}$. The cells were stained with methylene blue in $10 \%$ formaldehyde and plaques were counted. Viral titres were expressed as plaque forming unit per millilitre $(\mathrm{pfu} / \mathrm{mL})$.

\section{Statistical analysis}

Statistical analysis was performed using Statistical Package of Social Sciences (SPSS) software, version 25. All assays were performed in three independent experiments (biological replicates) and the values were presented as mean \pm standard error (SE). Data from all the experiments except virucidal assays had normal distribution and thus, were analysed by using one-way ANOVA with Tukey's post-hoc test. 
Data with non-normal distribution were analysed by Kruskalwallis test. $P$ value 0.05 was considered to be statistically significant.

\section{RESULTS}

\section{Cytotoxic of Tualang honey}

Prior to determining the potential anti-CHIKV activity of Tualang honey, its cytotoxic effect on Vero cells was investigated. Appropriate dose of honey that would not cause toxicity to Vero cells must be established such that cell changes during antiviral studies were affected solely by CHIKV. In this study, the viability of cells was inversely proportional to honey concentration and $\geq 90 \%$ of Vero cells were viable when exposed to $\leq 20 \mathrm{mg} / \mathrm{mL}$ Tualang honey (Figure 1). As such, nontoxic dose of Tualang honey at $5 \mathrm{mg} /$ $\mathrm{mL}, 10 \mathrm{mg} / \mathrm{mL}, 15 \mathrm{mg} / \mathrm{mL}$ and $20 \mathrm{mg} / \mathrm{mL}$ were selected for further antiviral experiments as described below.

\section{Virucidal activity of Tualang honey}

The ability of Tualang honey to kill or inactivate CHIKV directly was investigated by incubating $5,10,15$ or $20 \mathrm{mg} / \mathrm{mL}$ of Tualang honey directly with different amounts of CHIKV; $2 \mathrm{x}$ $10^{5}, 2 \times 10^{4}$, and $2 \times 10^{3} \mathrm{pfu}$. As shown in Figure 2, Tualang honey possess a moderate killing activity when $2 \times 10^{5} \mathrm{pfu} /$ $\mathrm{mL}$ of CHIKV was exposed to $10 \mathrm{mg} / \mathrm{mL}$ and $15 \mathrm{mg} / \mathrm{mL}$ Tualang honey with inhibitory effect of $67.64 \%$ and $77.61 \%$, respectively. The exposure of lower amount of CHIKV, $2 \times 10^{4} \mathrm{pfu}$ and $2 \times 10^{3}$ pfu, to various concentration of Tualang honey resulted in a dose-dependent virucidal effect. At $2 \times 10^{4} \mathrm{pfu}$ of CHIKV, Tualang honey at $15 \mathrm{mg} / \mathrm{mL}$ and $20 \mathrm{mg} / \mathrm{mL}$ caused CHIKV titres to reduce from $\log _{10} 5.71$ to 4.71 and $4.35 \mathrm{pfu} / \mathrm{ml}$, respectively (90\% and $95.63 \%$ reduction). Tualang honey had the greatest virucidal activity when it was exposed to $2 \times 10^{3} \mathrm{pfu}$ CHIKV, the lowest amount of virus tested in this study. The viral titres reduced from $\log _{10} 5.82$ to $4.25,3.83,3.57$ and $3.27 \mathrm{pfu} / \mathrm{mL}$ (97.30\%, 98.97\%, 99.43\% and $99.71 \%$ reduction, $p<0.05)$ upon incubation with $5 \mathrm{mg} / \mathrm{mL}, 10 \mathrm{mg} / \mathrm{mL}, 15 \mathrm{mg} / \mathrm{mL}$ and $20 \mathrm{mg} / \mathrm{mL}$, respectively (Figure 2 ).

\section{Effect of pre-treatment assay}

The ability of Tualang honey to confer protection to Vero cells prior to CHIKV infection was evaluated by pre-treatment assay. To examine the effect of concentration and incubation period of honey, Vero cells were pre-incubated with $5 \mathrm{mg} /$ $\mathrm{mL}, 10 \mathrm{mg} / \mathrm{mL}, 15 \mathrm{mg} / \mathrm{mL}$ or $20 \mathrm{mg} / \mathrm{mL}$ for $2,4,6,12$ or 24 hours followed by CHIKV infection. In general, Tualang honey pretreatment on Vero cells affected CHIKV replication although it was more influenced by the pre-treatment time rather than honey concentration (Figure 3). At 12-hour pre-treatment, Tualang honey at various concentrations exerted similar levels of inhibition (reduced from $\log _{10} 7.25 \mathrm{pfu} / \mathrm{ml}$ to $\log _{10}$ $6.80 \mathrm{pfu} / \mathrm{ml}$ and below). The highest inhibitory effect of Tualang honey was observed when Vero cells were exposed for 24 hours prior to CHIKV challenge (Figure 3). Statistically significant reduction at this time point was demonstrated following pre-treatment with $5 \mathrm{mg} / \mathrm{mL}$ and $10 \mathrm{mg} / \mathrm{mL}$ Tualang honey. Viral replication decreased from $\log _{10} 7.31 \mathrm{pfu} / \mathrm{mL}$ to 5.65 and $5.56 \mathrm{pfu} / \mathrm{mL}$, respectively $(97.81 \%$ and $98.22 \%$ reduction, $p<0.05$ ) (Figure 3 ).

\section{Effect of post-treatment assay}

Post-treatment assay was conducted to determine the antiviral activities of Tualang honey against CHIKV. Vero cells were infected with CHIKV and various concentrations of honey were added at 2, 4, 6 or $8 \mathrm{hpi}$. Based on the plaque assay results obtained at $48 \mathrm{hpi}$, post-incubation of CHIKV-infected Vero cells with Tualang honey at $4 \mathrm{hpi}$ resulted in a viral reduction. When exposed to $5 \mathrm{mg} / \mathrm{mL}$ and $10 \mathrm{mg} / \mathrm{mL}$ honey, viral titres significantly decreased from $\log _{10} 7.06 \mathrm{pfu} / \mathrm{mL}$ to 6.20 and $6.12 \mathrm{pfu} / \mathrm{mL}$, respectively $(86.19 \%$ and $88.51 \%$ reduction, $p<0.05$ ) (Figure 4). Similarly, CHIKV titres declined from $\log _{10} 6.85 \mathrm{pfu} / \mathrm{mL}$ to $6.21,5.96$ and $6.04 \mathrm{pfu} / \mathrm{mL}(77.09 \%$, $87.11 \%$ and $84.51 \%$ reduction) when 5,10 , and $15 \mathrm{mg} / \mathrm{mL}$ honey was added at $6 \mathrm{hpi}$, respectively (Figure 4). Interestingly, the most significant inhibitory effect was observed when between 5 to $15 \mathrm{mg} / \mathrm{mL}$ honey were added 8 hours after CHIKV infection. Viral titres diminished from $\log _{10} 6.65 \mathrm{pfu} / \mathrm{mL}$ to

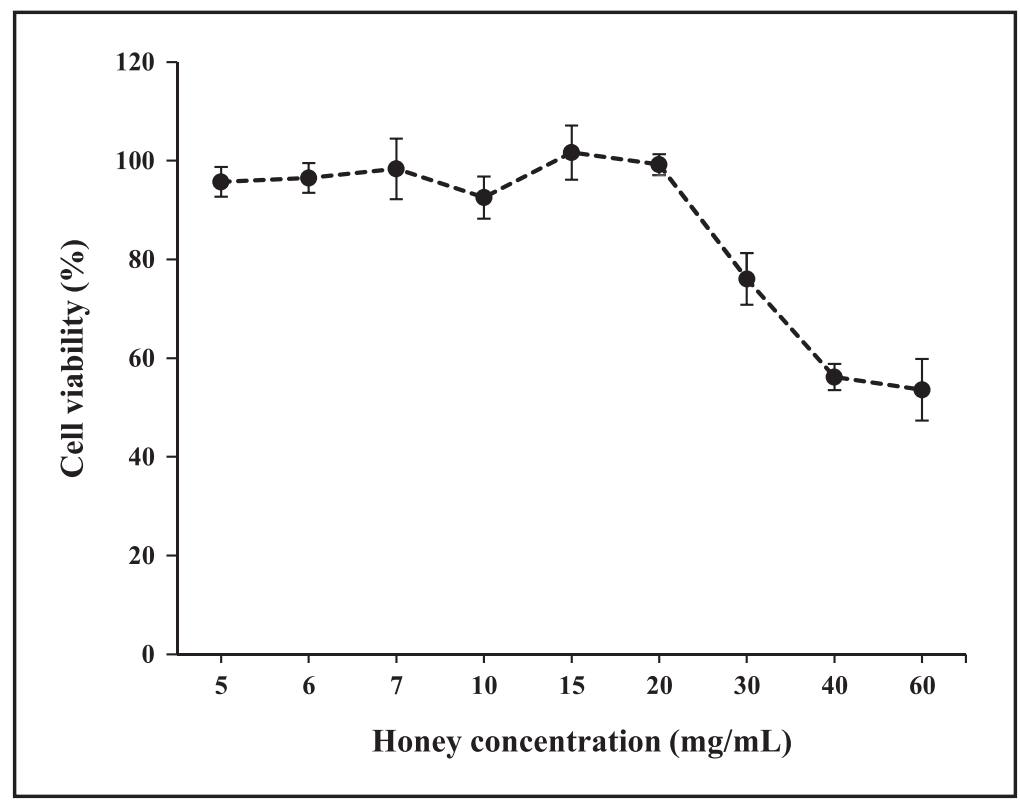

Figure 1. Cytotoxicity analysis of Tualang honey on Vero cells. The assay was performed after 48 hours of treatment with various concentrations of Tualang honey. The results are presented as percentage of cell viability in triplicates. 


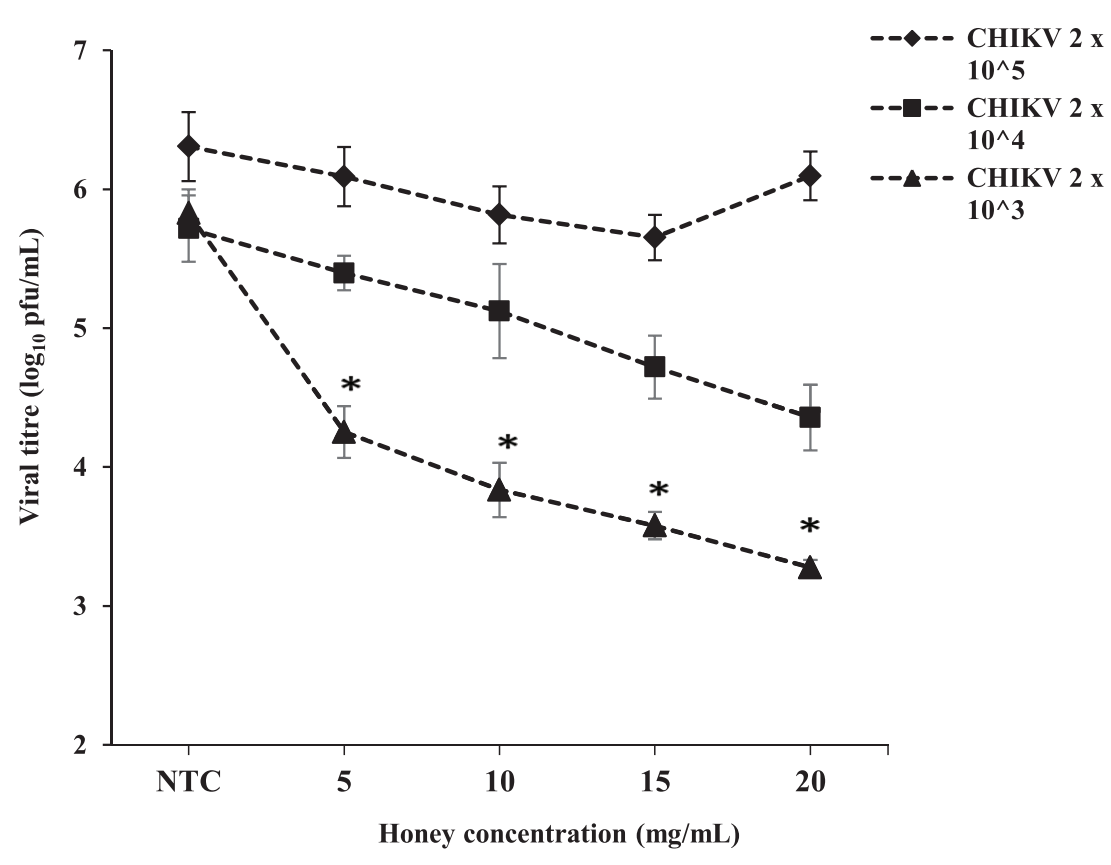

Figure 2. Virucidal activity of Tualang honey against different amounts of CHIKV. NTC refers to non-treated control, which was CHIKV-infected Vero cells without Tualang honey treatment. Values were expressed as mean \pm SE and $p<0.05$ was considered statistically significant $(*)$.

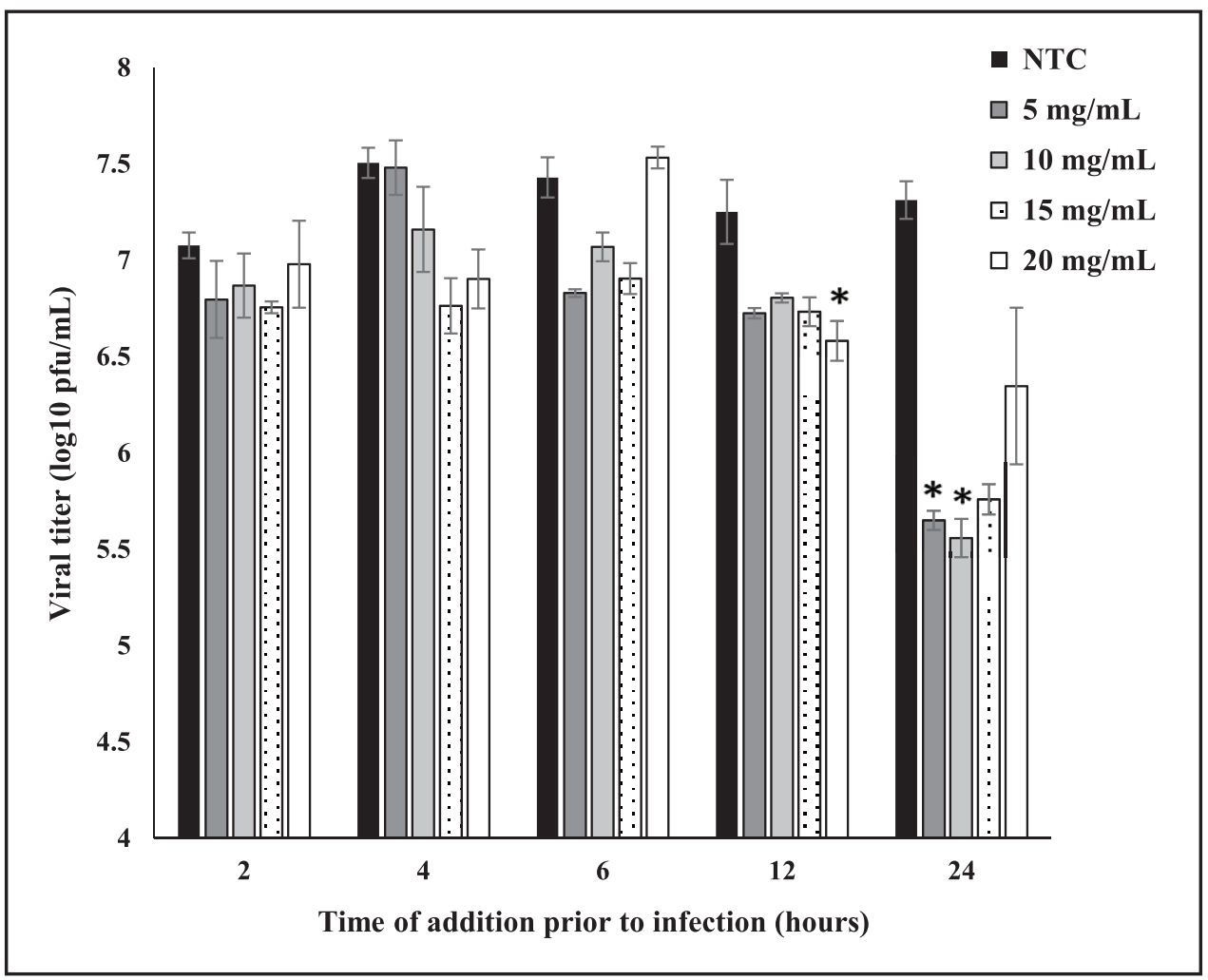

Figure 3. The effect of Tualang honey pre-treatment at different concentrations and hours on CHIKV replication. Vero cells were pre-incubated with Tualang honey at 2, 4, 6, 12 and 24 hours. Viral titres were monitored $48 \mathrm{hpi}$. NTC refers to non-treated control, which was CHIKV-infected Vero cells without Tualang honey treatment. Values were expressed as mean \pm SE and $p<0.05$ was considered statistically significant $(*)$. 
$\log _{10} 5.75,5.61$ and $5.36 \mathrm{pfu} / \mathrm{mL}$, respectively $(87.41 \%, 90.87 \%$ and $94.87 \%$ inhibition, $p<0.05$ ) (Figure 4 ).

\section{Anti-adsorption and anti-entry assays}

As shown in Figure 5a, Tualang honey did not exert inhibitory effect during anti-adsorption assay as CHIKV replication was similar between CHIVK-infected Vero cells without Tualang honey pre-treatment (NTC) $\left(\log _{10} 7.42\right)$ and CHIVK-infected Vero cells treated with different concentrations of honey (between $\log _{10} 7.24$ to $7.36 \mathrm{pfu} / \mathrm{mL}$ ). In contrast, during antientry assay, CHIKV titres had reduced from $\log _{10} 7.25 \mathrm{pfu} / \mathrm{mL}$ to $\log _{10} 6.69,6.56,6.50$ and $6.54 \mathrm{pfu} / \mathrm{mL}$ (72.45\%, 79.58\%, 82.21\%, and $80.50 \%$ reduction) upon treatment with $5,10,15$ and 20 $\mathrm{mg} / \mathrm{mL}$ of Tualang honey, respectively (Figure $5 \mathrm{~b}$ ), suggesting a moderate anti-entry activity of Tualang honey.

\section{DISCUSSION}

Tualang honey possesses numerous biological activities including antimicrobial, anticancer, antioxidant and wound healing (Ghashm et al., 2010; Khoo et al., 2010; Moniruzzaman et al., 2013). The composition, physicochemical properties, and pharmacokinetic of Tualang honey have been previously reported (Khalil et al., 2011; Jaafar et al., 2012). Tualang honey has various phenolic acids including gallic, syringic, benzoic, trans-cinnamic, p-coumaric, caffeic acid and flavonoid compounds such as catechin, kaempferol, naringenin, luteolin and apigenin (Khalil et al., 2011). However, the actual composition of this honey varies depending on geographical region, floral and entomological sources and storage time (Jaafar et al., 2012). Tualang honey has a dark colour intensity, indicating a higher levels of phenolic and flavonoid compounds compared with Manuka honey and other Malaysian honeys (Kishore et al., 2011). Manuka honey is a monofloral honey obtained from the manuka tree (Leptospermum scoparium) which naturally grows in New Zealand and Australia (Alvarez-Suarez et al., 2014). Unlike Tualang honey, Manuka honey has been extensively studies for its various antimicrobial activities against many pathogens.

To the best of our knowledge, data pertaining to the antiviral activities of Tualang honey is still lacking. Hence, in this preliminary study, the potential effects of Tualang honey towards CHIKV were investigated through various assays as Tualang honey could directly inactivate or interfere with various CHIKV replication stages such as attachment, viral entry, and RNA viral replication. In this study, Tualang honey was demonstrated to have viral dose and honey concentration dependent virucidal activities against CHIKV. Tualang honey may exert its virucidal activity by inactivating the free virus particles which eventually may affect CHIKV infection rate in Vero cells. Similar to our finding, Manuka honey was shown to possess direct killing activity against influenza and varicella zoster virus (Watanabe et al., 2014). Meanwhile, hepatitis C virus inactivation occurred directly following exposure to natural compound chebulagic acid (CHLA) and punicalagin (PUG) which protected the cell from subsequent infection (Tai et al., 2015). In the current study, although reduced viral replication was demonstrated, Tualang honey did not exert significant virucidal activity when exposed to the highest dose of CHIKV. This could be because the concentration of honey may be insufficient in comparison to the number of CHIKV particles present. Hence, a higher number of CHIKV particles may not be inhibited leading to insignificant viral reduction. Perhaps, Tualang honey virucidal activity can be bolstered if the concentration is increased proportionately to the viral concentration/number of particles.

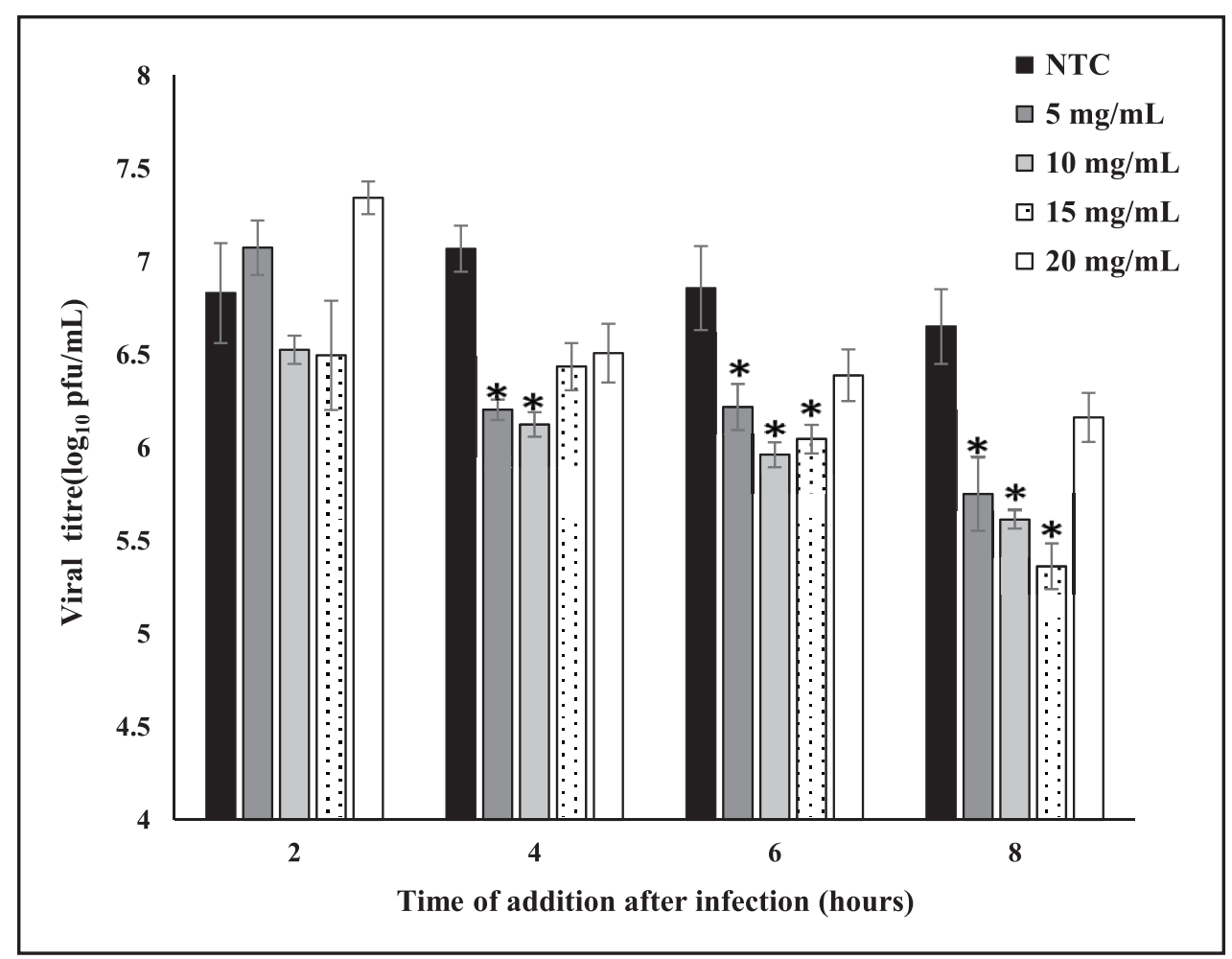

Figure 4. The effect of Tualang honey post-treatment at different concentrations and hours on CHIKV replication. NTC refers to non-treated control, which was CHIKV-infected Vero cells without Tualang honey treatment. Values were expressed as mean $\pm \mathrm{SE}$ and $p<0.05$ was considered statistically significant $\left({ }^{*}\right)$. 


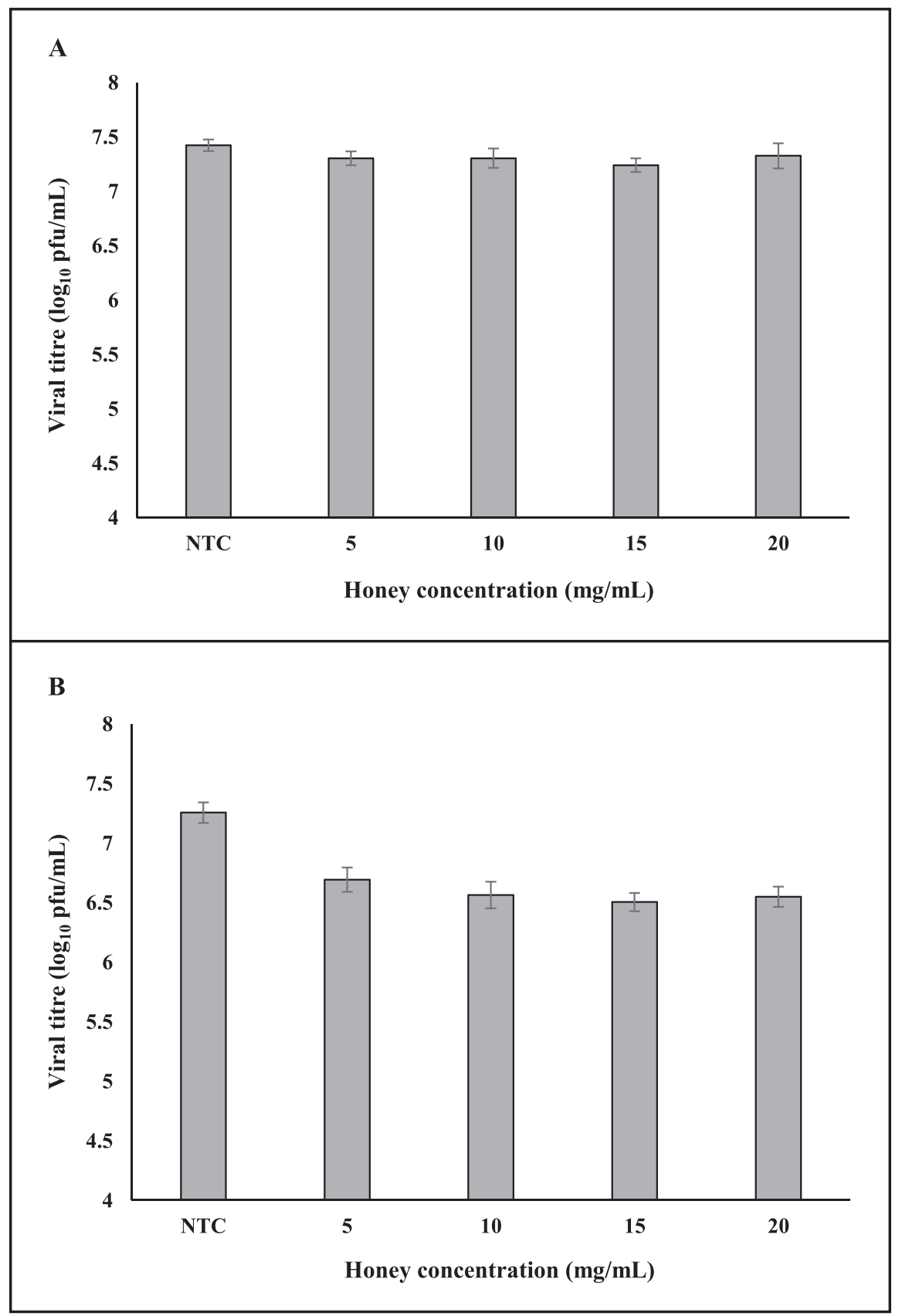

Figure 5. The effect of Tualang honey on CHIKV (a) adsorption and (b) entry. NTC refers to non-treated control, which was CHIKV-infected Vero cells without Tualang honey treatment. Values were expressed as mean $\pm \mathrm{SE}$ and $p<0.05$ was considered statistically significant $(*)$.

Tualang honey was demonstrated in this study to possess good prophylactic activities against CHIKV. The 24-hour pretreatment conferred the most protection to the cells from CHIKV infection, resulting in as much as $98.22 \%$ viral inhibition. Perhaps this is because prolonged exposure to Tualang honey enabled cells to be protected sufficiently and prevented CHIKV from interacting with its target receptor on Vero cells and eventually from initiating replication. As such, Tualang honey has therapeutic potential at least at in vitro level if appropriate amount of honey is used at the right time. In contrast, it was demonstrated that Manuka honey could not confer cell protection against influenza virus following pre-treatment with $6.25 \mathrm{mg} / \mathrm{mL}$ or $25 \mathrm{mg} / \mathrm{mL}$ of honey (Watanabe et al., 2014). A separate study had shown that Manuka honey was also unable to protect cell from respiratory syncytial virus infection (RSV) (Zareie, 2011). Future study should be performed to shed further light on the different prophylactic activities of Tualang and Manuka honeys.

The post-treatment assay suggests that Tualang honey also affects the intracellular activities of CHIKV such as replication of viral RNA or translation/assembly of viral protein in infected Vero cells. As much as $94.87 \%$ inhibition of CHIKV replication was observed following treatment at 8 hours after CHIKV infection. Given that Tualang honey did not directly affect CHIKV binding and moderately disrupt CHIKV entry, as demonstrated by the anti-adsorption and anti-entry assays, respectively, this suggests that Tualang honey confers its strongest anti-CHIKV effect after viral entry, although it is not known currently at which CHIKV replication 
stage is affected. Post-treatment of Manuka honey was shown to affect RSV replication by inhibiting the virus at the translation and transcription level as a reduction of viral mRNA was observed (Zareie, 2011). Methylglyoxal which is a major antibacterial compound in honey was shown to also possess great antiviral activity as it suppressed RSV activity. Methylglyoxal in some Iranian monofloral honeys has been shown to affect the late stage of HIV infection by blocking the assembly of new virion (Behbahani, 2014). Meanwhile, flavonoid apigenin extract was reported to interrupt viral RNA that is associated with host trans-acting factors during enterovirus 71 infection (Zhang et al., 2014). Thus, it is possible that Tualang honey could suppress CHIKV replication through the action of certain bioactive compounds, although further study is needed to verify this.

The in vitro anti-CHIKV activity of Tualang honey also could be contributed by its other flavonoid and phenolic contents. Luteolin in Tualang honey could be another compound of interest. Luteolin has potent anti-Japanese encephalitis virus (JEV) activity as it exerts extracellular virucidal activity and inhibits JEV replication after viral entry stage (Fan et al., 2016). As mentioned earlier, apigenin is a flavonoid compound that is also present in Tualang honey and previous study reported that apigenin suppressed CHIKV replication by having 5,7-dihydroxyflavone structure that targets CHIKV replication rather than entry (Pohjala et al., 2011). It will be of interest to elucidate the role of these compounds in Tualang honey during CHIKV infection.

It should be noted here that higher Tualang honey concentration does not correlate with better anti-CHIKV activity (Figure 3 and 4). In general, Tualang honey at $20 \mathrm{mg} /$ $\mathrm{mL}$ did not have superior antiviral activity than the lower Tualang honey concentrations used during pre-treatment and post-treatment assays. In fact, this particular honey concentration not only caused the least reduction of viral titres, it sometimes also resulted in enhancement of CHIKV replication. This finding agrees with Muller and co-workers (2011) who observed an augmentation of yellow fever virus and dengue virus replication following exposure to crude venoms and isolated toxin from a South American rattlesnake. Similarly, flavone was also shown to enhance dengue virus replication when added during and after virus adsorption (Zandi et al., 2012). It is possible that at higher Tualang honey concentration, significant amount of particular component may present that could promote either viral binding/entry or intracellular activities associated with viral replication. As such, future study should include determining effective dose for Tualang honey as inappropriate dosage might have adverse effect on CHIVK-infected host.

Taken together, this study provides further insights on the antiviral properties of Tulang honey and demonstrated that Tualang honey exerts in vitro anti-CHIKV activities through different mechanisms, by direct inactivation of CHIKV, protecting cells from CHIKV infection or affecting the intracellular activities during CHIKV replication. However, these results should be interpreted with cautious due to several limitations in the study. Firstly, the study was conducted using Vero cells which is of non-human origin, therefore it should not be presumed that similar effects would be observed in other cells particularly human cells or in vivo until further validation. As previous study has shown that certain medicinal plants have different antiviral effects depending on the host cells used (Husin et al., 2015), further testing in appropriate cells or animal models is needed. Lastly, the current study did not incorporate known antiviral agent such as ribavirin and therefore the efficacy of Tualang honey to inhibit CHIKV replication compare to a reference compound is unknown.

\section{ACKNOWLEDGEMENT}

This study was supported by Tabung Insentif Pembangunan Pengajian Siswazah PPSP (TIPPS) 2017 and USM Bridging Grant (304.PPSP.6316148).

\section{Conflict of Interests}

The author declare that they have no conflict of interests.

\section{REFERENCES}

Ahmed, S. \& Othman, N.H. (2013). Review of the medicinal effects of Tualang honey and a comparison with Manuka honey. Malaysian Journal of Medical Sciences 20: 6-13.

Alvarez-Suarez, J.M., Gasparrini, M., Forbes-Hernandez, T.Y., Mazzoni, L. \& Giampieri, F. (2014). The composition and biological activity of honey: A focus on Manuka honey. Foods 3: 420-432. https://doi.org/10.3390/foods3030420

Bashkaran, K., Zunaina, E., Bakiah, S., Sulaiman, S.A., Sirajudeen, K \& Naik, V. (2011). Anti-inflammatory and antioxidant effects of Tualang honey in alkali injury on the eyes of rabbits: Experimental animal study. International Society for Complementary Medicine Research 11: 90. https://doi.org/10.1186/1472-6882-11-90

Behbahani, M. (2014). Anti-HIV-1 activity of eight monofloral Iranian honey types. PLoS One 9: e108195. https://doi.org/ 10.1371/journal.pone.0108195

Bernard, E., Solignat, M., Gay, B., Chazal, N., Higgs, S., Devaux, C. \& Briant, L. (2010). Endocytosis of chikungunya virus into mammalian cells: Role of clathrin and early endosomal compartments. PLoS One 5: e11479. https://doi.org/ 10.1371/journal.pone.0011479

Chan, Y.S., Khoo, K.S. \& Sit, N.W. (2016). Investigation of twenty selected medicinal plants from Malaysia for antichikungunya virus activity. International Microbiology 19: 175182. https://doi.org/10.2436/20.1501.01.275

De Lamballerie, X., Boisson, V., Reynier, J.C., Enault, S., Charrel, R.N., Flahault, A., Roques, P. \& Grand, R.L. (2008). On chikungunya acute infection and chloroquine treatment. Vector Borne Zoonotic Disease 8: 837-839. https://doi.org/ 10.1089/vbz.2008.0049

Deeba, F., Islam, A., Kazim, S.N., Naqvi, I.H., Broor, S., Ahmed, A. \& Parveen, S. (2016). Chikungunya virus: recent advances in epidemiology, host pathogen interaction and vaccine strategies. Pathogen Disease 74: ftv119-110. https://doi.org/ 10.1093/femspd/ftv119

Devasvaran, K. \& Yong, Y.K. (2016). Anti-inflammatory and wound healing properties of Malaysia Tualang honey. Current Science 110: 47-51. https://doi.org/10.18520/cs/v110/ i1/48-52

Fan, W., Qian, S., Qian, P. \& Li, X. (2016). Antiviral activity of luteolin against Japanese encephalitis virus. Virus Research 220: 112-116. https://doi.org/10.1016/j.virusres. 2016.04.021

Ghashm, A.A., Othman, N.H., Khattak, M.N., Ismail, N.M. \& Saini, R. (2010). Antiproliferative effect of Tualang honey on oral squamous cell carcinoma and osteosarcoma cell lines. BMC Complementary and Alternative Medicine 10: 49. https://doi.org/10.1186/1472-6882-10-49

Heang, V., Yasuda, C.Y., Sovann, L., Haddow, A.D., Travassos da Rosa, A.P., Tesh, R.B. \& Kasper, M.R. (2012). Zika virus infection, Cambodia, 2010. Emerging Infectious Diseases 18: 349-351. https://doi.org/10.3201/eid1802.111224

Husin, F., Chan, Y.Y., Gan, S.H., Sulaiman, S.A. \& Shueb, R.H. (2015). The effect of Hydrocotyle sibthorpioides Lam. extracts on in vitro dengue replication. Evidence Based Complementary and Alternative Medicine 2015: 1-9. https:// doi.org/10.1155/2015/596109 
Jaafar, M.H.M., Hamid, K.A., Anuar, N., Zohdi, R.M. \& Effendi, T.J.B. (2012). Physicochemical properties and pharmacokinetic profiles of selected Malaysian honey. 2012 IEEE Symposium on Business, Engineering and Industrial Applications 140-145. https://doi.org/10.1109/ISBEIA.2012.6422856

Khalil, M.I., Alam, N., Moniruzzaman, M., Sulaiman, S.A. \& Gan, S.H. (2011). Phenolic acid composition and antioxidant properties of Malaysian honeys. Journal of Food Science 76: C921-928. https://doi.org/10.1111/j.1750-3841. 2011.02282.x

Khan, M., Santhosh, S.R., Tiwari, M., Lakshmana Rao, P.V. \& Parida, M. (2010). Assessment of in vitro prophylactic and therapeutic efficacy of chloroquine against chikungunya virus in Vero cells. Journal of Medical Virology 82: 817-824. https://doi.org/10.1002/jmv.21663

Khoo, Y.T., Halim, A.S., Sing, K.K. \& Mohamad, N.A. (2010). Wound contraction and anti-microbial properties of Tualang honey on full thickness burn wound in rats in comparison to hydrofibre. BMC Complementary and Alternative Medicine 10: 48. https://doi.org/10.1186/1472-6882-10-48

Kishore, R.K., Halim, A.S., Syazana, M.S. \& Sirajudeen, K.N. (2011). Tualang honey has higher phenolic content and greater radical scavenging activity compared with other honey sources. Nutrition Research 31: 322-325. https:// doi.org/10.1016/j.nutres.2011.03.001

La Beaud, A.D. (2008). Why Arboviruses Can Be Neglected Tropical Diseases. PLoS Neglected Tropical Diseases 2: e24. https://doi.org/10.1371/journal.pntd.0000247

Lani, R., Hassandarvish, P., Chiam, C.W., Moghaddam, E., Chu, J.J.H., Rausalu, K., Merits, A., Higgs, S., Vanlandingham, D., Bakar, S.A. \& Zandi, K. (2015). Antiviral activity of silymarin against chikungunya virus. Scientific Reports $\mathbf{5}$ : 1-10. https://doi.org/10.1038/srep11421

Mishra, P., Kumar, A., Mamidi, P., Kumar, S., Basantray, I., Saswat, T., Das, I., Nayak, TK., Chattopadhyay, S., Subudhi, B.B. \& Chattopadhyay, S. (2016). Inhibition of chikungunya virus replication by 1-[(2-Methylbenzimidazol-1-yl) Methyl]-2Oxo-Indolin-3-ylidene] Amino] Thiourea (MBZM-N-IBT). Scientific Reports 6: 20122. https://doi.org/10.1038/srep20122

Mohamat, S.A., Shueb, R.H. \& Che Mat, N.F. (2018). Anti-viral activities of Oroxylum indicum extracts on chikungunya virus infection. Indian Journal of Microbiology 58: 68-75. https:// doi.org/10.1007/s12088-017-0695-8

Moniruzzaman, M., Khalil, M.I., Sulaiman, S.A. \& Gan, S.H. (2013). Physicochemical and antioxidant properties of Malaysian honeys produced by Apis cerana, Apis dorsata and Apis mellifera. BMC Complementary and Alternative Medicine 13: 43. https://doi.org/10.1186/1472-6882-13-43

Morrison, T.E. (2014). Reemergence of chikungunya virus. Journal of Virology 88: 11644-11647. https://doi.org/10.1128/ JVI.01432-14

Morrone, A. (2007). Poverty, health and development in dermatology. International Journal of Dermatology 46: 1-9. https://doi.org/10.1111/j.1365-4632.2007.03540.x

Muller, V.D., Russo, R.R., Cintra, A.C., Sartim, M.A., Alves-Paiva Rde, M., Figueiredo, L.T., Sampaio, S.V. \& Aquino, V.H. (2012). Crotoxin and phospholipases $\mathrm{A}_{2}$ from Crotalus durissus terrificus showed antiviral activity against dengue and yellow fever viruses. Toxicon 59: 507-515. https://doi.org/ 10.1016/j.toxicon.2011.05.021

Naresh Kumar, C.V.M., Anthony Johnson, A.M. \& Sai Gopal, D.V.R. (2007). Molecular characterization of chikungunya virus from Andhra Pradesh, India \& phylogenetic relationship with Central African isolates. Indian Journal of Medical Research 126: 534-540.
Perera-Lecoin, M., Luplertlop, N., Surasombatpattana, P., Liegeois, F., Hamel, R., Thongrungkiat, S., Vargas, R.E.M., Yssel, H. \& Misse, D. (2016). Dengue and chikungunya coinfection - The Emergence of an underestimated threat. In: Current topics in chikungunya, Rodriguez-Morales AJ. September edition. Rijeka, Croatia: IntechOpen, pp.67104.

Pohjala, L., Utt, A., Varjak, M., Lulla, A., Merits, A., Ahola, T. \& Tameela, P. (2011). Inhibitors of alphavirus entry and replication identified with a stable chikungunya replicon cell line and virus-based assays. PLoS One 6: e28923. https://doi.org/10.1371/journal.pone.0028923

Rothan, H.A., Bahrani, H., Mohamed, Z., Teoh, T.C., Shankar, E.M., Rahman, N.A. \& Yusof, R. (2015). A combination of doxycycline and ribavirin alleviated chikungunya Infection. PLoS One 10: e0126360. https://doi.org/10.1371/ journal.pone. 0126360

Sanyaolu, A., Okorie, C., Badaru, O., Wynveen, E., White, S., Wallace, W., Akl, J., Freeze, A., Kamel, A., Madonna, M., Mathur, A., Moran, R. \& Perry, C. (2016). Chikungunya epidemiology: A global perspective. SM Journal of Public Health and Epidemiology 2: 1028.

Schuffenecker, I., Iteman, I., Michault, A., Murri, S., Franguel, L., Vaney, M.C., Lavenir, R., Pardigon, N., Reynes, J.M., Pettinelli, F., Biscornet, L., Diancourt, L., Michel, S., Duquerroy, S., Guigon, G., Frenkiel, M.P., Brehin, A.C., Cubito, N., Despres, P., Kunst, F., Rey, F.A., Zeller, H. \& Brisse, S. (2006). Genome microevolution of chikungunya viruses causing the Indian Ocean outbreak. PLoS Medicine 3: e263. https://doi.org/10.1371/journal.pmed.0030263

Steinmann, J., Buer, J., Pietschmann, T. \& Steinmann, E. (2013). Anti-infective properties of epigallocatechin-3-gallate (EGCG), a component of green tea. British Journal of Pharmacology 168: 1059-1073. https://doi.org/10.1111/bph. 12009

Tai, C.J., Li, C.L., Tai, C.J., Wang, C.K. \& Lin, L.T. (2015). Early viral entry assays for the identification and evaluation of antiviral compounds. Journal of Visualized Experiments 104: e53124. https://doi.org/10.3791/53124

Von Rhein, C., Weidner, T., Henß, L., Martin, J., Weber, C., Silva, K. \& Schnierle, B.S. (2016). Curcumin and Boswellia serrata gum resin extract inhibit chikungunya and vesicular stomatitis virus infections in vitro. Antiviral Research 125: 51-57. https://doi.org/10.1016/j.antiviral.2015.11.007

Watanabe, K., Rahmasari, R., Matsunaga, A., Haruyama, T. \& Kobayashi, N. (2014). Anti-influenza viral effects of honey in vitro: potent high activity of Manuka honey. Archives of Medical Research 45: 359-65. https://doi.org/10.1016/ j.arcmed.2014.05.006

Zandi, K., Teoh, B.-T., Sam, S.-S., Wong, P.-F., Mustafa, M.R. \& AbuBakar, S. (2011). Antiviral activity of four types of bioflavonoid against dengue virus type-2. Virology Journal 8: 560 . https://doi.org/10.1186/1743-422X-8-560

Zareie, P.P. (2011). Honey as an antiviral agent against respiratory syncytial virus. University of Waikato. https://hdl.handle.net/10289/5291

Zhang, W., Qiao, H., Lv, Y., Wang, J., Chen, X., Hou, Y., Tan, R. \& Li, E. (2014). Apigenin inhibits enterovirus-71 infection by disrupting viral RNA association with trans-acting factors. PLoS One 9: e110429. https://doi.org/10.1371/journal.pone. 0110429 